\title{
AKTIVITAS ANTIOKSIDAN DAN ANTIKOLESTEROL EKSTRAK RUSIP
}

\section{Antioxidant and Anticholesterol Activity of Rusip Extract}

\author{
Rinto*, Shanti Dwita Lestari, dan Nanda Anggiani Putri \\ Program Studi Teknologi Hasil Perikanan, Jurusan Perikanan, Fakultas Pertanian Universitas Sriwijaya, Indralaya, \\ Sumatera Selatan, Indonesia \\ *Korespondensi Penulis: rinto@fp.unsri.ac.id
}

Diterima: 21 November 2018; Direvisi: 18 Maret 2019; Disetujui: 13 Juni 2019

\begin{abstract}
ABSTRAK
Rusip merupakan produk fermentasi hasil perikanan yang dihasilkan oleh bakteri asam laktat yang mengandung peptida bioaktif. Penelitian ini bertujuan untuk mengetahui rendemen, kadar peptida, serta aktivitas antioksidan dan antikolesterol ekstrak rusip. Penelitian ini menggunakan dua jenis rusip, yaitu rusip A yang memiliki aktivitas antioksidan terbaik dan rusip B yang memiliki aktivitas antikolesterol terbaik didasarkan pada hasil penelitian sebelumnya. Ekstraksi dilakukan dengan metode maserasi tunggal menggunakan aquabides, dilanjutkan dengan fraksinasi berdasarkan perbedaan berat molekul. Uji antioksidan dilakukan dengan metode 2,2'-azino-bis (3-ethylbenzthiazoline-6-sulphonic acid) (ABTS) dan uji antikolesterol dilakukan dengan metode penghambatan aktivitas enzim HMG-KoA reduktase. Hasil penelitian memperlihatkan fraksi F1 (berat molekul $>10 \mathrm{kDa}$ ) memiliki rendemen yang paling tinggi baik pada rusip $A$ maupun rusip B dengan rendemen berturut-turut sebesar 16,61\% dan 14,14\%. Kadar peptida tertinggi rusip A dan rusip $B$ terdapat pada fraksi $E$ (ekstrak utuh) yaitu masing-masing sebesar $1,22 \%$ dan $1,25 \%$. Aktivitas antioksidan tertinggi pada rusip A terdapat pada fraksi F3 (berat molekul $<1 \mathrm{kDa}$ ) dengan nilai hambatan sebesar $62,90 \%$ pada dosis $1 \mathrm{mg} / \mathrm{mL}$ dan aktivitas antikolesterol tertinggi terdapat pada fraksi F2 (berat molekul 1-10 kDa) dengan nilai inhibisi sebesar $50 \%$ pada dosis $5 \mathrm{mg} / \mathrm{mL}$. Aktivitas antikolesterol dan antioksidan fraksi rusip tersebut tergolong rendah dibanding produk fermentasi ikan lainnya.
\end{abstract}

KATA KUNCI : antioksidan, antikolesterol, ekstrak rusip

\begin{abstract}
Rusip is a fermented product which is produced by lactic acid bacteria containing bioactive peptide. The purpose of this research was to study the yield, peptide content, antioxidant and anticholesterol of rusip extract. This study used two types of rusip, i.e. rusip $A$ which had the best antioxidant activity and rusip $B$ that had the best anticholesterol activity based on the results of previous studies. Rusip was extracted by single maceration methode used aquabidest and continued with fractionation based on differences in molecular weight. Antioxidant assay was conducted using 2,2'-azino-bis (3-ethylbenzthiazoline-6-sulphonic acid) (ABTS) methode and anticholesterol assay by inhibition of HMG-CoA reductase enzyme methode. The result showed that F1 fraction (molecular weight $>10 \mathrm{kDa}$ ) had the highest yield both in the rusip $A$ and rusip B, i.e $16.61 \%$ and $14.14 \%$ respectively. The highest peptide content of the rusip $A$ and rusip $B$ was obtained from $E$ fraction (whole extract), i.e. $1.22 \%$ and $1.25 \%$ respectively. The rusip fraction with highest antioxidant activity of rusip $A$ was $F 3$ fraction (molecular weight $<1 \mathrm{kDa}$ ) that had inhibition of $62.90 \%$ (concentration of $1 \mathrm{mg} / \mathrm{mL}$ ) and the highest activity of anticholesterol was F2 fraction (molecular weight 1-10 kDa) with inhibition of $50 \%$ (concentration of $5 \mathrm{mg} / \mathrm{mL}$ ). The antioxidant and anticholesterol activity of the rusip extract was low ompared to other fish fermented products.
\end{abstract}

KEYWORDS: antioxidant, anticholesterol, rusip extract

\section{PENDAHULUAN}

Fermentasi merupakan proses perubahan senyawa kompleks yang berasal dari substrat organik menjadi komponen-komponen sederhana oleh aktivitas mikroba maupun enzim dalam keadaan yang terkontrol (Chadong, Yunchhalard, \& Piyatheerawong, 2015). Selama proses fermentasi dihasilkan komponen bioaktif berupa peptida bioaktif dan komponen organik lainnya yang memiliki sifat fungsional. Peptida bioaktif dapat berasal atau diturunkan dari makanan dan memiliki fungsi baik pada 
manusia. Peptida bioaktif dapat ditemukan pada telur, susu, daging dan ikan. Aktifitas peptida bioaktif sebagai antimikroba, antitrombotik, antihipertensi, antioksidan dan antikolesterol dapat dipengaruhi oleh banyaknya urutan peptida (Kitts \& Weiler, 2003). Peptida bioaktif antioksidan dan antikolesterol yang berasal dari bahan makanan dapat dikembangkaan sebagai suplemen maupun pangan fungsional. Hal ini dapat digunakan untuk membantu mengatasi permasalahan penghambatan/penyumbatan pembuluh darah yang disebabkan oleh hiperkolesterolemia dan oksidasi kolesterol darah.

Beberapa produk fermentasi yang mengandung peptida bioaktif dan memiliki sifat fungsional antara lain susu, beras merah (angkak) dan bekasam. Susu terfermentasi merupakan sumber nutrisi dan juga sebagai sumber senyawa bioaktif dalam bentuk protein alamiahnya maupun peptida yang memiliki sifat fungsional sebagai antihipertensi, antimikroba, antioksidan, antitrombotik dan imunomodulator (Kusumaningtyas, Widiastuti, Kusumaningrum, \& Suhartono, 2015). Beras merah (angkak) terfermentasi berfungsi sebagai antikolesterol. Senyawa antikolesterol yang terdapat pada angkak adalah lovastatin (Kasim, Suharna, \& Nurhidayat, 2006). Bekasam juga memiliki sifat fungsional sebagai antioksidan dan antikolesterol. Peneliti sebelumnya menyebutkan bahwa bekasam memiliki sifat fungsional sebagai antikolesterol (Rinto, Dewanti, Yasni, \& Suhartono, 2017a). Oleh karena itu perlu dilakukan pengkajian antioksidan dan antikolesterol terhadap produk fermentasi ikan lainnya, di antaranya rusip.

Rusip merupakan salah satu produk fermentasi berbentuk cairan. Proses pengolahan rusip menggunakan bahan yang berasal dari berbagai jenis ikan yang tidak memiliki nilai ekonomis tinggi menggunakan bakteri asam laktat. Rusip berpotensi mengandung senyawa bioaktif berupa peptida (Rinto \& Subarka, 2017). Oleh karena itu, fraksinasi lebih lanjut diperlukan untuk mengkaji peptida bioaktif dari rusip yang berfungsi sebagai antioksidan maupun antikolesterol. Penelitian ini bertujuan untuk mengetahui rendemen ekstrak kasar dan hasil fraksinasi, kadar peptida, aktivitas antioksidan dan antikolesterol pada fraksi ekstrak rusip.

\section{BAHAN DAN METODE}

\section{Bahan}

Bahan utama yang digunakan dalam penelitian adalah rusip yang diperoleh dari Pangkal Pinang, Bangka Belitung. Bahan kimia yang digunakan dalam analisa adalah aquabides (Pharmaceutical Laboraotories), KIT HMG-KoA reduktase (Sigma Aldrich), indikator PP/fenolftalein (Sigma Aldrich), $\mathrm{NaOH}$ (Sigma Aldrich), formaldehid (Sigma Aldrich), tablet 2,2'-azino-bis (3-ethylbenzthiazoline-6-sulphonic acid) (ABTS) (Sigma Aldrich), potassium persulfat (Sigma Aldrich) dan bahan kimia lain yang mendukung penelitian. Semua bahan kimia yang digunakan merupakan bahan kimia pro-analisis.

\section{Tempat dan Waktu}

Penelitian ini dilaksanakan di Laboratorium Kimia dan Biokimia Hasil Perikanan serta Laboratorium Kimia Hasil Pertanian, Fakultas Pertanian Universitas Sriwijaya. Selain itu, penelitian juga dilaksanakan di Laboratorium Kimia, Fakultas Matematika dan IImu Pengetahuan Alam, Universitas Sriwijaya. Penelitian dilaksanakan pada bulan September sampai dengan November 2017.

\section{Metode}

Penelitian ini menggunakan metode experimental laboratorium dan analisa data dilakukan secara deskriptif. Penelitian dilakukan secara bertahap yaitu ekstraksi rusip, pengukuran rendemen ekstrak rusip, fraksinasi ekstrak rusip, pengukuran rendemen hasil fraksinasi ekstrak rusip, analisis kadar peptida, analisis antioksidan dengan metode ABTS, dan analisis antikolesterol dengan metode Inhibisi HMG Ko-A reduktase. Semua tahap perlakuan diulang sebanyak tiga kali dengan menggunakan pelarut aquabides. Rusip yang digunakan dalam penelitian ini terdiri dari dua jenis yaitu rusip $A$ yang memiliki aktivitas antioksidan terbaik dan rusip $B$ yang memiliki aktivitas antikolesterol terbaik didasarkan pada hasil penelitian sebelumnya (Rinto \& Subarka, 2017).

\section{Ekstraksi rusip}

Ekstraksi rusip dilakukan dengan tahapan sebagai berikut: sebanyak $10 \mathrm{~g}$ rusip dihomogenisasi dengan $40 \mathrm{~mL}$ aquabides dan diaduk selama 30 menit pada suhu ruang. Ekstrak disaring dengan kertas saring Whatman 01 menghasilkan filtrat (1) dan residu. Kemudian residu dihomogenisasi kembali dengan menambahkan $50 \mathrm{~mL}$ aquabides dan diaduk selama 30 menit pada suhu ruang. Ekstrak disaring dengan kertas saring Whatman 01 menghasilkan filtrat (2). Filtrat 1 dan 2 dicampur kemudian disentrifugasi dengan kecepatan $6.000 \mathrm{rpm}$, pada suhu $4^{\circ} \mathrm{C}$ selama 15 menit menghasilkan supernatan dan presipitat. Kemudian ekstrak rusip dievaporasi menggunakan waterbath dengan suhu $70^{\circ} \mathrm{C}$ selama \pm 7 sampai 8 jam untuk menguapkan pelarut yang ada di fitrat (Itou \& Akahene, 2009; Itou \& Akahene, 2010). Rendemen 
ekstrak kasar ditentukan berdasarkan Hustiany (2005) menggunakan rumus sebagai berikut:

Rendemen ekstrak $(\%)=\frac{\text { Berat akhir ekstrak }}{\text { Berat rusip }} \times 100 \%$

\section{Fraksinasi ekstrak rusip}

Fraksinasi dilakukan berdasarkan perbedaan berat molekul dengan metode Rinto, Nopianti, Herpandi, \& Oktaviani (2017b) yang telah dimodifikasi. Ekstraksi rusip dengan aquabides pada tahap sebelumnya menghasilkan fraksi $E$ (ekstrak utuh). Fraksi $E$ kemudian diambil sebanyak $1 \mathrm{~mL}$ dan ditambahkan $9 \mathrm{~mL}$ aquabides, kemudian dihomogenkan dengan vortek dan dilakukan fraksinasi menggunakan penyaringan concentrator tube spesifkasi MWCO 10 $\mathrm{kDa}$ yang disentrifugasi pada $9.000 \mathrm{rpm}$ pada $4{ }^{\circ} \mathrm{C}$ selama 3 menit. Pada tahap ini menghasilkan fraksi $\mathrm{F} 1$ dengan berat molekul $>10 \mathrm{kDa}(\mathrm{BM}>10 \mathrm{kDa})$ yang terdapat pada tabung bagian atas. Filtrat yang terdapat di tabung bagian bawah disaring menggunakan syringe filter $0,02 \mathrm{~mm}$. Supernatan pada tabung bagian atas yang dihasilkan merupakan fraksi F2 dengan berat molekul 1-10 kDa (BM 1-10 $\mathrm{kDa}$ ) dan yang lolos dari syringe filter pada tabung bagian bawah merupakan fraksi F3 dengan berat molekul $<1 \mathrm{kDa}(\mathrm{BM}<1 \mathrm{kDa})$. Masing-masing fraksi digunakan untuk pengujian aktivitas antikolesterol dan antioksidan. Perhitungan rendemen fraksi rusip menggunakan persamaan:

Rendemen fraksi $(\%)=\frac{\text { Berat akhir fraksi }}{\text { Berat rusip }} \times 100 \%$

\section{Kadar peptida}

Penentuan kadar peptida dilakukan dengan menggunakan titrasi formol. Sebanyak $0,25 \mathrm{~mL}$ ekstrak sampel dilarutkan dengan $4,75 \mathrm{~mL}$ aquabides dan dimasukan kedalam erlenmeyer $250 \mathrm{~mL}$. Kemudian sampel yang sudah dilarutkan ditambah $10 \mathrm{~mL}$ aquabides dan $\pm 0,5 \mathrm{~mL}$ indikator PP. Lalu sampel ditritasi dengan $\mathrm{NaOH} 0,1 \mathrm{~N}$ sampai bewarna merah muda. Sampel ditambah $1 \mathrm{~mL}$ larutan formaldehid $40 \%$ dan dititrasi kembali dengan $\mathrm{NaOH}$ (Wikandari \& Yuanita, 2014). Kadar peptida ditentukan melalui persamaan:

$$
N(\%)=(a /(b \times 10)) \times N ~ N a O H \times A r N \times f p
$$

Keterangan:

$\mathrm{a}=$ Volume Titrasi Formol

$\mathrm{b}=$ Berat Sampel

$\mathrm{fp}=$ Faktor Pengenceran

\section{Analisis antioksidan dengan metode ABTS}

Analisis aktivitas antioksidan rusip A menggunakan metode ABTS berdasarkan Kusumaningtyas et al. (2015) dengan tahapan sebagai berikut: larutan stok ABTS dibuat dengan melarutkan ABTS sebanyak $34,142 \mathrm{mg}$ ke dalam $1.000 \mathrm{~mL}$ pelarut aquabides. Sebanyak $1 \mathrm{~mL}$ larutan ABTS dicampur dengan $1 \mathrm{~mL}$ larutan potassium persulfat (perbandingan 1:1) untuk dijadikan sebagai larutan blanko. Untuk uji aktivitas antioksidan dibuat kembali larutan blanko sebanyak seri standar atau sampel (ekstrak rusip A) yang digunakan dan dicampur dengan masing-masing $1 \mathrm{~mL}$ standar/sampel ekstrak rusip A. Kemudian didiamkan dalam kondisi gelap selama 16-18 jam. Standar antioksidan yang digunakan yaitu butylated hydroxytoluene (BHT) dengan konsentrasi 10, 20, 30, 40, 50 dan $60 \mathrm{ppm}$. Dosis ekstrak rusip yang digunakan sebesar $1 \mathrm{mg} / \mathrm{mL}$. Pengukuran absorbansi dilakukan dengan menggunakan spektrofotometri pada panjang gelombang $405 \mathrm{~nm}$. Aktivitas antioksidan pada uji ABTS dapat dihitung dengan persamaan:

$\underset{\text { Antioksidan (\%) }}{\text { Aktivitas }}=\frac{(\text { Abs blanko }- \text { Abs sampel })}{\text { Abs blanko }} \times 100 \%$

Keterangan :

${ }^{*}$ Abs blanko = Absorbansi hasil reaksi larutan ABTS + potassium persulfat

${ }^{*}$ Abs sampel $=$ Absorbansi hasil reaksi ABTS + potassium persulfat dan sampel

\section{Analisis antikolesterol dengan inhibisi HMG- KoA Reduktase}

Uji aktivitas antikolestrol rusip B dilakukan menggunakan KIT HMG-KoA reduktase CS1090. Prosedur uji dilakukan sesuai tahapan pada kit. Secara ringkas prosedur uji dilakukan sebagai berikut: semua reagen yang digunakan (enzim HMG-KoA reduktase, buffer, NADPH, subtrat HMG-KoA, dan pravastatin dicairkan dalam refrigerator ataupun dalam es untuk menjaga suhu tetap dingin). Sebelum dimulai, spektrofotometer diatur pada panjang gelombang $340 \mathrm{~nm}$ dan reagen ditambahkan sesuai dengan prosedur seperti yang terlihat pada Tabel 1. Pravastatin digunakan sebagai inhibitor kontrol positif terhadap HMG-KoA reduktase. Dosis ekstrak rusip dan kontrol positif yang digunakan dalam pengujian ini sebesar $5 \mathrm{mg} / \mathrm{mL}$. Pengujian dilakukan secara periodik mulai menit pertama waktu inkubasi (setelah semua bahan dimasukan/dicampur) dan dilajutkan setiap menit berikutnya selama 15 menit, pada kondisi suhu ruang $\left( \pm 28^{\circ} \mathrm{C}\right)$. Penurunan nilai absorbansi 
secara periodik di setiap menit menunjukan aktivitas enzim HMG-KoA reduktase dan laju penurunan absorbansi menunjukan penghambatan aktivitas enzim HMG-KoA reduktase (Lachenmeir et al., 2012).

Aktivitas enzim dihitung dengan persamaan:

Unit/mg $P=\frac{\left(\left(\Delta \mathrm{A}_{340} / \min _{\text {sampel }}\right)-\left(\Delta \mathrm{A}_{340} / \min _{\text {blank }}\right)\right) \times \mathrm{TV}}{(12,44 \times \mathrm{V} \times 0,6 \times \mathrm{LP})}$

Keterangan:

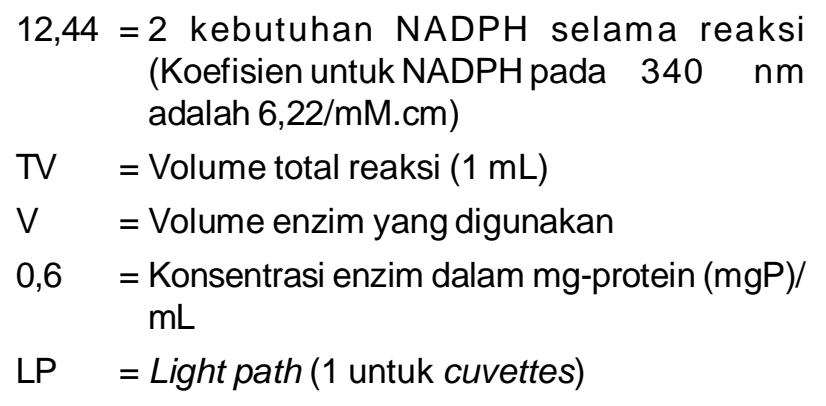

\section{HASIL DAN PEMBAHASAN}

\section{Rendemen Ekstraksi Rusip}

Rendemen ekstrak merupakan perbandingan antara ekstrak yang dihasilkan dengan jumlah sampel awal yang diekstrak rusip dan dinyatakan dalam bentuk persen. Perhitungan rendemen ekstrak dilakukan untuk mengukur efektivitas pelarut yang digunakan untuk mengekstrak komponen bioaktif yang terkandung didalam sampel. Rendemen ekstrak rusip A dan B dapat dilihat pada Tabel 2.

Pelarut yang digunakan untuk mengekstrak rusip yaitu pelarut aquabides. Menurut Hustiany (2015) aquabides memiliki keunggulan dibandingkan dengan lainnya, yaitu dari segi keamanannya tidak bersifat toksik serta terbebas dari kontaminan mikroba dan garam-garam anorganik sehingga dapat memperkecil peluang ekstrak kasar terkontaminasi. Rusip merupakan produk olahan fermentasi berbentuk cair yang menghasilkan peptida yang bersifat polar, oleh karena itu aquabides baik digunakan untuk mengekstrak peptida dari rusip.

\section{Rendemen Hasil Fraksinasi Ekstrak Rusip}

Fraksinasi bertujuan untuk memisahkan komponen bioaktif (peptida) berdasarkan perbedaan berat molekulnya serta menguji aktivitas antioksidan dan antikolesterol setiap fraksi. Fraksinasi ekstrak rusip ini menghasilkan 3 fraksi yaitu $\mathrm{F} 1(\mathrm{BM}>10 \mathrm{kDa})$; F2 (BM 1-10 KDa); dan F3 (BM <1 KDa). Rendemen hasil fraksinasi ekstrak rusip $A$ dan $B$ dapat dilihat pada Tabel 3.

Tabel 1. Volume reagen uji inhibitor HMG-KoA reduktase

Table 1. Volume of reagent in HMG-KoA reductase inhibitor assay

\begin{tabular}{lcccccc}
\hline \multicolumn{1}{c}{ Sampel/Sample } & $\begin{array}{l}\text { Bufer/ } \\
\text { Buffer }\end{array}$ & Inhibitor & NADPH & $\begin{array}{c}\text { Subtrat } \\
\text { HMG-KoA/ } \\
\text { HMG-KoA } \\
\text { Substrate }\end{array}$ & $\begin{array}{c}\text { Enzim } \\
\text { HMG-KoA/ } \\
\text { HMG-KoA } \\
\text { Enzyme }\end{array}$ & $\begin{array}{c}\text { Aquabides/ } \\
\text { Aquabidest }\end{array}$ \\
\hline $\begin{array}{l}\text { Blanko/Blank } \\
\text { Aktivitas enzim/ }\end{array}$ & $920 \mu \mathrm{L}$ & - & $20 \mu \mathrm{L}$ & $60 \mu \mathrm{L}$ & - & 1500 \\
$\begin{array}{l}\text { Enzyme activity } \\
\text { Inhibisi }\end{array}$ & $915 \mu \mathrm{L}$ & - & $20 \mu \mathrm{L}$ & $60 \mu \mathrm{L}$ & $5 \mu \mathrm{L}$ & 1500 \\
$\begin{array}{l}\text { Pravastatin/sampel/ } \\
\text { Inhibition of pravastini } \\
\text { sample*) }\end{array}$ & $910 \mu \mathrm{L}$ & $5 \mu \mathrm{L}$ & $20 \mu \mathrm{L}$ & $60 \mu \mathrm{L}$ & $5 \mu \mathrm{L}$ & 1500 \\
\hline
\end{tabular}

*) Konsentrasi pravastatin/sampel $=5 \mu \mathrm{L} / 1000 \mu \mathrm{L}(5.000 \mathrm{ppm}) /$ Pravastatin/sample concentration $=5 \mu \mathrm{L} / 1000 \mu \mathrm{L}$ (5.000 ppm)

Tabel 2. Rendemen ekstrak rusip A dan rusip $B$

Table 2. Yield of Rusip $A$ and $B$

\begin{tabular}{cc}
\hline Sampel/Sample & Rendemen/Yield (\%) \\
\hline Rusip A & $20.83 \pm 0.05$ \\
Rusip B & $21.33 \pm 0.04$ \\
\hline
\end{tabular}

Keterangan/Notes:

Rusip A : Rusip yang memiliki aktivitas antioksidan terbaik/Rusip with the highest antioxydant activity

Rusip B : Rusip yang memiliki aktivitas antikolesterol terbaik/Rusip with the highest anticholesterol activity 
Tabel 3. Rendemen fraksi ekstrak rusip Table 3. Yield of rusip extract fractions

\begin{tabular}{lcc}
\hline \multicolumn{1}{c}{ Fraksi Ekstrak Rusip/ } & \multicolumn{2}{c}{ Rendemen/Yield (\%) } \\
\cline { 2 - 3 } \multicolumn{1}{r}{ Rusip extract fractions } & A & B \\
\hline F1 $(\mathrm{BM}>10 \mathrm{KDa})$ & $16.61 \pm 0.07$ & $14.14 \pm 0.05$ \\
F2 $(\mathrm{BM} 1-10 \mathrm{KDa})$ & $1.55 \pm 0.05$ & $2.56 \pm 0.05$ \\
F3 $(\mathrm{BM}<1 \mathrm{KDa})$ & $2.06 \pm 0.07$ & $2.33 \pm 0.03$
\end{tabular}

* \% rendemen merupakan nilai rata-rata diperoleh dari 3 kali ulangan/\% rendement was the average of 3 replication

Rendemen terbesar terdapat pada fraksi F1 (BM $>10 \mathrm{kDa}$ ) dengan rerata rendemen rusip $A$ yaitu $16,61 \%$ dan rusip $B$ yaitu $14,14 \%$. Hal ini menunjukkan bahwa ekstrak rusip didominasi oleh peptida dengan berat molekul besar $(\mathrm{BM}>10 \mathrm{kDa})$, baik dari rusip $A$ maupun rusip $B$. Kondisi ini disebabkan oleh bahan baku yang sama dari pembuatan rusip yang berupa ikan teri/bilis.

\section{Kadar Peptida Ekstrak Rusip}

Peptida merupakan molekul yang tersusun dari dua sampai dengan 50 asam amino, namun jika jumlah asam amino lebih dari 50 molekul disebut dengan protein. Penentuan kadar peptida pada penelitian ini dilakukan dengan titrasi formol. Titik akhir titrasi terjadi jika terdapat perubahan warna menjadi merah muda. Nilai rata-rata kandungan peptida yang terdapat pada rusip A dan rusip B dapat dilihat pada Gambar 1 .
Berdasarkan hasil penelitian penentuan kadar peptida, rata-rata kadar peptida rusip $A$ yang dihasilkan berkisar $0,32-1,22 \%$ sedangkan rusip $B$ berkisar $0,38-1,25 \%$. Kadar peptida yang terdapat pada masing-masing fraksi (Gambar 1) sebanding dengan rendemen hasil fraksinasi (Tabel 3). Hal ini menunjukan bahwa semakin besar rendemen yang dihasilkan akan mengandung peptida semakin banyak. Ekstraksi menggunakan aquades akan menghasilkan senyawa yang bersifat polar di antaranya peptida.

Secara umum peptidabioaktif pada produk fermentasi akan menyebabkan produk memiliki fungsi sebagai pangan fungsional. Beberapa peptida dari produk-produk fermentasi telah terbukti memiliki sifat fungsional misalnya peptida dari bekasam sebagai antikolesterol (Rinto et al., 2017b) dan antihipertensi (Wikandari \& Yuanita, 2014), serta peptida dari susu kambing sebagai

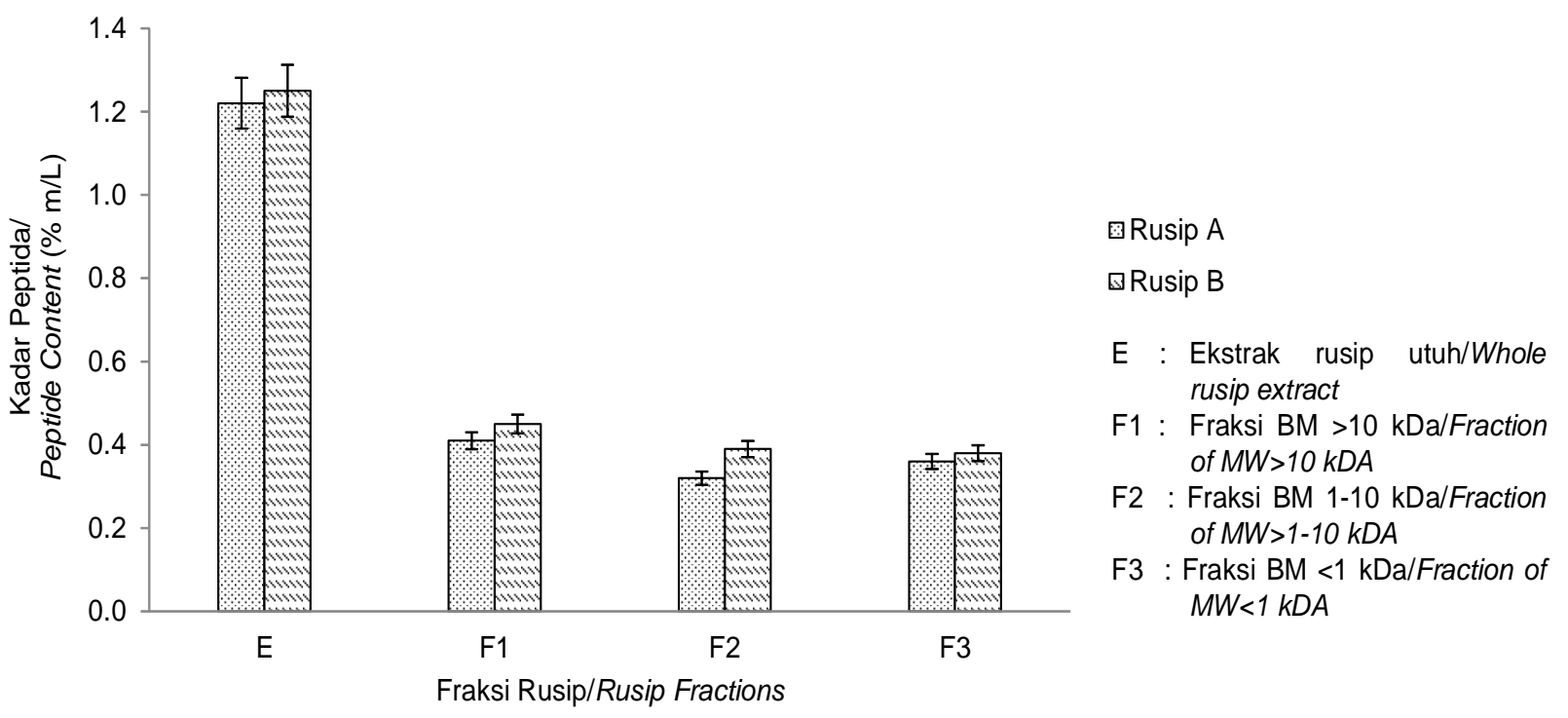

Gambar 1. Kadar peptida ekstrak rusip A dan B

Figure 1. Peptide contents of rusip $A$ and $B$ 
antioksidan (Kusumaningtyas et al., 2015). Kemampuan peptida sebagai antikolesterol disebabkan karena kemampuan peptida dalam menghambat aktivitas enzim HMG-KoA reduktase. Enzim HMG-KoA reduktase merupakan enzim yang berperan penting dalam sintesis kolesterol. Penghambatan aktivitas HMG-KoA reduktase dapat menurunkan kandungan kolesterol dalam darah (Rinto et al., 2017b).

\section{Aktivitas Antioksidan Ekstrak Rusip}

Antioksidan merupakan senyawa kimia yang dapat menyumbangkan satu atau lebih elektron kepada radikal bebas, sehingga dapat meredam radikal bebas di dalam tubuh. Secara alamiah, tubuh manusia mensintesis antioksidan alami, namun tidak mempunyai cadangan antioksidan dalam jumlah berlebih, sehingga paparan radikal yang berlebihan menyebabkan tubuh membutuhkan antioksidan dari luar (Zulfahmi, Yoyok, Antonius, 2014). Untuk mengetahui kemampuan antioksidan dalam suatu bahan dapat diketahui dengan melakukan uji aktivitas antioksidan. Uji aktivitas antioksidan pada penelitian ini menggunakan metode ABTS (Damgaard, Otte, Meinert, Jensen, Lametsch, 2014). Intensitas perubahan warna yang terjadi pada ABTS dapat diukur absorbansinya dengan menggunakan spektrofotometer pada panjang gelombang $405 \mathrm{~nm}$.

Berdasarkan Tabel 4. dapat diketahui bahwa aktivitas antioksidan rata-rata ekstrak rusip A berkisar antara $10,11 \%$ sampai $62,90 \%$. Aktivitas antioksidan yang tertinggi terdapat pada fraksi F3 (BM <1 kDa) dengan rata-rata inhibisi $62,90 \%$ sedangkan inhibisi yang terendah terdapat pada $E$ (ekstrak utuh) dengan rata-rata $10,11 \%$. Hal ini menunjukkan bahwa fraksinasi bisa meningkatkan nilai antioksidan, terbukti dengan meningkatnya aktivitas antioksidan berturut-turut mulai dari F1 (BM >10 kDa) sampai F3 $(\mathrm{BM}<1 \mathrm{kDa})$. Fraksinasi yang dilakukan memisahkan berbagai peptida bioaktif berdasarkan berat molekul, sehingga masing-masing fraksi yang terbentuk semakin murni. Peningkatan aktivitas antioksidan setelah adanya fraksinasi menunjukkan peningkatan aktivitas antioksidan yang disebabkan oleh proses pemurnian rusip. Pada konsentrasi ekstrak rusip dibawah $0,1 \mathrm{mg} / \mathrm{mL}$, semua ekstrak rusip maupun fraksi rusip A tidak menunjukkan adanya aktivitas antioksidan, meskipun demikian nilai aktivitas fraksi rusip menunjukkan peningkatan sejalan dengan kemurnian ekstrak. Dalam penelitian ini, BHT yang digunakan sebagai kontrol positif memiliki $I_{50}$ sebesar 88,98 ppm, sehingga antioksidan ekstrak rusip jauh di bawah standar BHT.

Pada tempe yang merupakan produk fermentasi berbahan kedelai, fraksi peptida dengan rendemen terbanyak berada pada kisaran berat molekul $<1 \mathrm{kDa}$ serta $>8 \mathrm{kDa}$. Fraksi tersebut juga menunjukkan aktivitas terbaik pada uji antioksidan. Penghambatan aktivitas antioksidan yang baik yaitu di atas $75 \%$ pada konsentrasi 0,1 mg/mL (Rusdah, Suhartono, Palupi, \& Ogawa, 2017).

\section{Aktivitas Antikolesterol Ekstrak Rusip B}

Analisa terhadap kemampuan inhibisi dari ektrak rusip B terhadap aktivitas enzim HMG-KoA reduktase

Tabel 4. Hasil uji antioksidan ekstrak rusip A

Table 4. Result of antioxidant assay rusip extract $A$

\begin{tabular}{lc}
\hline \multicolumn{1}{c}{ Ekstrak Rusip/Rusip extract } & Penghambat / Inhibition (\%) \\
\hline E (ekstrak utuh) & $10.11 \pm 0.15$ \\
F1 (BM $>10 \mathrm{kDa})$ & $47.35 \pm 0.08$ \\
F2 (BM 1-10 kDa) & $58.08 \pm 0.04$ \\
F3 (BM < 1 kDa) & $62.90 \pm 0.09$ \\
\hline
\end{tabular}

Tabel 5. Hasil uji antikolesterol ekstrak rusip B (Inhibisi terhadap enzim HMG-KoA reduktase)

Table 5. Result of anticholesterol assay rusip extract B (Inhibition to HGM-CoA reductase enzyme)

\begin{tabular}{lc}
\hline \multicolumn{1}{c}{ Ekstrak Rusip/Rusip extract } & Penghambat/Inhibition (\%) \\
\hline E (ekstrak utuh) & $16.67 \pm 0.32$ \\
F1 (BM>10 kDa) & $33.33 \pm 0.25$ \\
F2 (BM 1-10 kDa) & $50.00 \pm 0.33$ \\
F3 (BM < $1 \mathrm{kDa})$ & $16.67 \pm 0.20$ \\
Pravastatin & $100.00 \pm 0.00$ \\
\hline
\end{tabular}


menunjukkan adanya daya inhibisi ekstrak rusip terhadap HMG-KoA reduktase. Nilai rata-rata inhibisi terhadap aktivitas enzim HMG-KoA reduktase berkisar antara $16,67 \%$ sampai $50 \%$ pada konsentrasi $5 \mathrm{mg} /$ $\mathrm{mL}$. Aktivitas masing-masing fraksi dari ekstrak rusip terhadap enzim HMG-KoA reduktase dapat dilihat pada Tabel 5.

Tabel 5 memperlihatkan bahwa pravastatin sebagai kontrol positif (standar) pada dosis 5000 ppm yang menunjukkan inhibisi $100 \%$ terhadap aktivitas enzim HMG-KoA reduktase. Penggunaan dosis $5 \mathrm{mg} / \mathrm{mL}$ merujuk pada metode yang ada pada KIT HMG-KoA reduktase. Pada fraksi ekstrak rusip, inhibisi tertinggi terdapat pada fraksi F2 (BM 1-10 kDa). Hal Ini menunjukkan peptida bioaktif dari ekstrak rusip yang berpotensi sebagai antikolesterol berada pada kisaran 1-10 kDa. Hal ini juga sejalan dengan penelitian Rinto et al. (2017a) yang menyatakan bahwa peptida antikolesterol dari ekstrak bekasam terdapat pada peptida dengan berat molekul 3-10 kDa. Analisis terhadap kemampuan inhibisi dari ekstrak rusip terhadap aktivitas enzim HMG-KoA reduktase tergolong rendah $(<75 \%)$ dibandingkan dengan ekstrak bekasam ikan seluang yang memiliki kemampuan inhibisi yang tinggi terhadap HMG-KoA reduktase $(92,86 \%)$ (Rinto et al., 2017a). Hal ini disebabkan karena fermentasi rusip berlangsung lebih lama dari pada bekasam, sehingga protein, peptida, maupun asam amino yang terbentuk akan semakin terurai menjadi komponen yang lebih sederhana oleh enzimenzim dari mikroorganisme yang berperan selama proses fermentasi. Hal ini sesuai dengan pendapat Anggo, Swastawati, Ma'ruf, \& Rianingsih (2014) yang menyatakan terjadinya penurunan kandungan protein dan asam amino khususnya glutamat pada terasi seiring dengan lamanya fermentasi.

\section{KESIMPULAN}

Rendemen terbanyak hasil fraksinasi ekstrak dari kedua jenis rusip terdapat pada F1 (BM >10 kDa) sebesar 16,61 pada rusip A dan 14,14\% pada rusip B. Kadar peptida rusip A yang dihasilkan sebesar 0.36$1,22 \%$ sedangkan rusip $B$ sebesar $0,38-1,25 \%$. Fraksi rusip A memiliki aktivitas antioksidan sebesar $62,90 \%$ pada dosis $1 \mathrm{mg} / \mathrm{mL}$ sedangkan fraksi rusip B memiliki aktivitas antikolesterol sebesar $50 \%$ pada konsentrasi $5 \mathrm{mg} / \mathrm{mL}$. Daya inhibisi tersebut tergolong rendah $(<75 \%)$, dibandingkan dengan inhibisi produk fermentasi ikan lainnya.

\section{UCAPAN TERIMA KASIH}

Terimakasih diberikan kepada Dirjen DIKTI, Kementerian Riset dan Pendidikan Tinggi, melalui Program Hibah Penelitian Fundamenta/Penelitian
Dasar Unggulan Perguruan Tinggi No Kontrak: 102/ SP2H/LT/DRPM/IV/2017, 2018 dan 2019.

\section{DAFTAR PUSTAKA}

Anggo, A. D., Swastawati, F., Ma'ruf, W. F., \& Rianingsih, L. (2014). Mutu organoleptik dan kimiawi terasi udang rebon dengan kadar garam berbeda dan lama fermentasi. Jurnal Pengolahan Hasil Perikanan Indonesia. 17 (1): 53-59.

Chadong, K., Yunchalard, S., \& Piyatheerawong, W. (2015). Physicochemical characteristics and protein degradation duringfermentation of Plaa-som, a traditional fermented fish productof North-Eastern Thailand. Indian Journal of Traditional Knowladge. 14 (2), 220-225.

Damgaard, T.D., Otte, J.A.H., Meinert, L., Jensen, K., \& Lametsch R. (2014). Antioxidant capacity of hydrolyzed porcine tissues. Food Sci Nutr., 2, 282288.

Hustiany, R. (2005). Karakteristik Produk olahan kerupuk dan surimi dan daging ikan patin (Pangasius sutchi) hasil budidaya sebagai sumber protein hewani. Media Gizi dan keluarga. 29 (2), 66-74.

Itou, K., \& Akahane, Y. (2009). Effect of extract from heshiko, a fermented mackerel product, on cholesterol metabolism in wistar rats. Fish Science. 75, 241 - 248. doi:10.1007/s12562-008-0035-3

Itou, K., \& Akahane, Y. (2010). Effect of extract from narezushi, a fermented mackerel product, on cholesterol metabolism in wistar rats. Fish Science. 76, 537- 546. doi:10.1007/s12562-010-0236-4

Kasim, E., Suharna, N., \& Nurhidayat, N. (2006). Kandungan pigmen dan lovastatin pada angkak beras merah kultivar Bah Butong dan BP 1804 IF 9 yang difermentasi dengan Monascus purpureus Jmba. Jurnal Biodiversitas. 7 (1), 7-9.

Kitts, D. D., \& Weiler, K. (2003). Bioactive proteins and peptides from food sources. Applications of bioprocesses used in isolation and recovery. Current Pharmaceutical Design, 9 (16), 1309-1323.

Kusumaningtyas, E., Widiastuti, R., Kusumaningrum, H.D., \& Suhartono, M.T. (2015). Aktivitas Antibakteri dan Antioksidan Hidrolisat Hasil Hidrolisis Protein Susu Kambing Dengan Ekstrak Kasar Bromelin. Bogor. Jurnal Teknologi dan Industri Pangan. 26(2), 179-188.

Lachenmeir, D. W., Monakhova, Y. B., Kuballa, T., LobellBehrends, S., Maixner, S., Kohl-Himmelseher, M., Waldner, A. \& Steffenm C. (2012). NMR evaluation of total statin content and HMG-CoA reductase inhibitor in red yeast rice food supplements. Chinese Medicine, 7 (8), 1-7.

Rinto, Dewanti, R., Yasni, S. \& Suhartono, M.T. (2015). Isolasi dan identifikasi bakteri asam laktat penghasil inhibitor enzim HMG-KoA reduktase dari bekasam sebagai agen pereduksi kolesterol. Jurnal Agritech. 35 (3), 309-314.

Rinto, Nopianti, R., Herpandi, \& Oktaviani, S. (2017). Fractionation of Anticholesterol Bioactive 
Compounds from Bekasam (Indonesian Fermented Fish Product). J. Trop. Agric. Sci., 40 (3), 399-406.

Rinto, Dewanti, R., Yasni, S. \& Suhartono, M.T. (2017). Novel HMG-CoA reductase inhibitor peptide from Lactobacillus acidophilus isolated from Indonesia fermented food bekasam. Journal of Pharmaceutical, Chemical and Biological Science. 5 (3), 195-204.

Rinto \& Subarka, A. (2017). Kajian kemanan dan kualitas rusip Bangka. Prosiding Seminar Nasional Fakultas Pertanian Unsri. 2017 : 680-685.

Rusdah, R., Suhartono, M. T., Palupi, N. S., \& Ogawa, M. (2017). Tingkat Kelarutan Peptida Tempe dengan
Bobot Molekul Kecil pada Berbagai Jenis Pelarut. Jurnal Agritech., 37 (3) , 327-333.

Wikandari, P. R., \& Yuanita, L. (2014). Potensi Bekasam yang Difermentasi dengan Lactobacillus plantarum B1765 dalam Menurunkan Tekanan Darah Tikus Hipertensi. Surabaya: Prosiding Seminar Nasional Kimia. Jurusan Kimia FMIPA Universitas Negeri Surabaya.

Zulfahmi, M., Yoyok, B.P. \& Antonius, H. (2014). Pengaruh marinasi ekstrak kulit nanas pada daging itik tegal betina afkir terhadap aktivitas antioksidan dan kualitas kimia. Jurnal Aplikasi Teknologi Pangan, 3(2), 46-48. 